\title{
Levels of Heavy Metal in Some Selected Fish Species Inhabiting Ondo State Coastal Waters, Nigeria
}

\author{
Johnson Olayinka Olusola* and Aiyesanmi Ademola Festus
}

Department of Chemistry, Federal University of Technology, Akure, Nigeria

\begin{abstract}
The distribution and level of six heavy metals viz: $\mathrm{Cr}, \mathrm{Cd}, \mathrm{Pd}, \mathrm{Cu}, \mathrm{Zn}$, and $\mathrm{Ni}$ in different organs gill, head, bone, muscle and eye of five fish species Arius latisculatus, Cynoglossus browni, Caranx lugubris, Sardinella aurita, Caranx senegallus, and associated water collected from the coastal waters of Ondo State, Southwestern Nigeria were investigated in this study. The concentrations of $\mathrm{Zn}(0.10-0.36 \mathrm{mg} / \mathrm{kg}), \mathrm{Cu}(0.18-0.27 \mathrm{mg} / \mathrm{kg}), \mathrm{Ni}(\mathrm{BDL}-0.01 \mathrm{mg} / \mathrm{kg})$ and $\operatorname{Cr}(0.04-0.63 \mathrm{mg} / \mathrm{kg})$ found in the water samples were within the Maximum Permissible Level (MPL), while higher concentrations above the MPL were recorded for $\mathrm{Cd}(0.08-0.19 \mathrm{mg} / \mathrm{kg})$ and $\mathrm{Pb}(0.34-0.79 \mathrm{mg} / \mathrm{kg})$. Zn was the $\mathrm{most}$ abundant heavy metals found in all fish species organs investigated. Higher concentrations of the metals were recorded in the gills and eyes compared to other organs in most of the fish species. While the concentration of $\mathrm{Zn}(0.28 \mathrm{mg} /$ $\mathrm{kg}-4.14 \mathrm{mg} / \mathrm{kg}$ ), $\mathrm{Cu}(\mathrm{BDL}-5.72 \mathrm{mg} / \mathrm{kg}$ ), Ni (BDL-0.01 mg/kg), and Cr (BDL-3.41) in the fish tissues were within the Maximum Allowable Level (MAL) for a food source, the findings of this study Cd (BDL-3.18 mg/kg) and Pd (BDL-1.14 $\mathrm{mg} / \mathrm{kg}$ ) showed values exceeding the maximum allowable level, thus constituting potential health hazard to consumers of these fish species. Transfer factors of most metals in fish from water were greater than or equal to 1 suggesting bioaccumulation of the metals by the fish from water column, while distribution of the heavy metals in the different fish parts were organ specific.
\end{abstract}

Keywords: Heavy metals; Bioaccumulation; Fish; Coastal water

\section{Introduction}

Fish and fishery products are generally regarded as important part of a healthy diet. In developing world, fish and fishery products apart from being a source of cheap animal protein, are widely consumed since they have high quality protein and other essential nutrients and are low in saturated fat and contain omega 3 fatty acids. Over the last fifty years, there has been an increase in the number of chemical compounds identified to be present in natural waters. Majority of these chemicals originate from various industrial activities and increasing urbanization facilitates their entry into rivers, lakes and ocean [1]. Ondo State is located in South Western Nigeria and has coastal areas estimated to be about 60,000 hectares. It is an oil producing state along other Niger Delta State such as Delta, Rivers, Bayelsa, Akwa Ibom etc. The surface area of marine and brackish water resources in Nigeria covers estimated area of $233,000 \mathrm{~km}^{2}$ [2] and the brackish-marine fishery potential has been estimated at 273,500 metric tonnes per annum [3].

The main marine-brackish water areas in Nigeria are found along the coastal zone which are characterized by expansive estuarine lagoon and mangroves swamps fronted by beach ridge barriers this extend from Lagos lagoon through Ondo State coaster waters to the Niger Delta in the South-south of Nigeria. Sustainability of fisheries resources in the coastal waters is now threatened by the introduction of oil into the ocean via oil spillage for the great majority of species which spend their earliest stages near coast, estuarine, brackish or freshwater. Exploration and exploitation activities of oil companies such as Shell, Chevron, Texaco etc. in the coastal region of Ondo State, Nigeria is one major way by which the natural coastal waters of Ondo State, Nigeria is being polluted. Oil spills could occur as result of release of crude oil from tankers, offshore platforms, drilling rigs and well, as well as spills of refined petroleum product (such as gasoline, diesel etc.) and their by-products and heavy fuel used by large ship. Oil spillage into water affects the ecosystem and its component negatively. Among animal species, fish are the inhabitant that cannot escape from the detrimental effects of these pollutants. Fish are widely used to evaluate the health of aquatic ecosystems because pollutants build up in the food chain and are responsible for adverse effects and death in the aquatic systems [4]. The major sources of heavy metals in water especially in the oil producing areas (like the study area) include crude oil, drilling fluids, or mud, agricultural activities, domestic wastes and natural sources that make up the background concentration. As heavy metal cannot be degraded, they are deposited, assimilated or incorporated in water, sediments and aquatic animals and thus causing heavy metal pollution in water bodies [5]. Therefore, heavy metals can be bioaccumulated and biomagnified via the food chain and finally assimilated by human consumers resulting in health risks [6].

Arius latisculatus known as roughhead sea catfish belongs to the family Ariidea. They live mainly in marine waters, freshwater and brackish waters. Ariidea catfish are found in shallow temperate and tropical seas around the coastlines of Africa, North and South America, Asia and Australia. Cynoglossus browni, commonly known as the Nigerian tonguesole is a species of tonguefish. It is commonly found in Eastern Atlantic Ocean off the coast of West Africa. Caranx lugubris and Caranx senegallus referred to as Black jack and Senegal jack respectively, belongs to the jack family Carangidae. The species is distributed through the tropical waters of the eastern Atlantic Ocean, to the West African coast. Carangidae are predatory fishes, taking a variety of small fishes, crabs and shrimps Sardinella aurita is a genus of fishes in the family Clupeidae, Sardinella species are generally coastal, schooling, marine fish. Juveniles are often found in lagoons and estuaries, and adults are more common

*Corresponding author: Olusola JO, Department of Chemistry, Federal University of Technology, Akure, Nigeria, Tel: 234-806-644-7549; E-mail: layinkx@gmail.com/ demolaktp@yahoo.co.uk

Received May 20, 2015; Accepted June 17, 2015; Published June 22, 2015

Citation: Olusola JO, Festus AA (2015) Levels of Heavy Metal in Some Selected Fish Species Inhabiting Ondo State Coastal Waters, Nigeria. J Environ Anal Toxicol 5: 303. doi:10.4172/2161-0525.1000303

Copyright: (c) 2015 Olusola JO, et al. This is an open-access article distributed under the terms of the Creative Commons Attribution License, which permits unrestricted use, distribution, and reproduction in any medium, provided the original author and source are credited. 
Citation: Olusola JO, Festus AA (2015) Levels of Heavy Metal in Some Selected Fish Species Inhabiting Ondo State Coastal Waters, Nigeria. J Environ Anal Toxicol 5: 303. doi:10.4172/2161-0525.1000303

Page 2 of 8

off the coast. They mainly abundant in warmer waters in both sides of the Atlantic Ocean, throughout the Mediterranean Sea, and in the Indian and the Western Pacific Oceans [7]. Most of this fish species feed in a variety of ways, ranging from sieving phytoplankton or grazing algae, to suction feeding on benthic invertebrates and to devouring other fishes whole or in portions [8].

The examined fish species have been used as bio-indicators to monitor heavy metals concentrations in the coastal environment, due to their wide range of distribution, feeding rate, their important position in the food chain, and also because they produce evidence of relatively stable concentration. The major occupation of the inhabitants in the coastal region is fishing, the water body and the examined fish species remains the sole source of livelihood for the inhabitants. As such, having understood that oil explorations and other industrial activities could result into heavy metal pollution of the aquatic system, it becomes imperative to continuously monitor the effect of this activity on the ecosystem. Recent studies have shown that because of high rates of pollution in aquatic environments especially in developed world as a result of increased urbanization and industrialization activities, fishes and fishery products contain traces of heavy metals which can be detrimental to the health of consuming public [9]. Heavy metal toxicity is frequently the result of long term low level exposure to pollutants common in our environment: air, water, food and numerous consumer products. Hence, high concentration of some essential trace metals such as $\mathrm{Cr}, \mathrm{Cu}$, and $\mathrm{Zn}$ may become toxic at concentrations exceeding the limits which are required. Therefore, humans who consume significant amount of fish may also be at risk.
The main objectives of the present work is to determine the concentration of dissolved heavy metals $(\mathrm{Pd}, \mathrm{Cd}, \mathrm{Cr}, \mathrm{Zn}, \mathrm{Cu}$, and $\mathrm{Ni}$ ) in water column of Ondo State coastal waters, estimate the accumulation of these heavy metals in the muscle, eyes, gills, head, and bones of some commercially important fish species from the coastal waters; and compare the levels of toxic metals in the examined fish species and water column with maximum allowable limits (MAL).

\section{Materials and Methods}

\section{Study area}

The study was carried out in Ilaje Local Government Area (ILGA) (Figure 1) in the coastal area of Ondo State, Nigeria in January 2014. ILGA is at the extreme Southern part of Ondo state. ILGA shares boundaries with Okitipupa Local Government Area in the North; the Atlantic Ocean in the South; Ijebu Waterside Local Government Area (Ogun State) in the West and Delta state in the East. Ilaje local government area is considered as one of the most important fishing areas in the coast which have rich biodiversity that contains a diverse assemblage of fish, shellfish (shrimps, crabs, lobster, gastropods and cephalopoda), reptiles and other living organisms [10]. ILGA comprised of several fishing communities located within the river tributaries discharging into the Atlantic and those along the coastline [11]. The study area is parallel to Nigeria Southwest coastline which is characterized by extensive lagoons and river delta systems. The area represents a reflection of what occurs physically, morphologically and environmentally in the adjoining areas. There is a large concentration

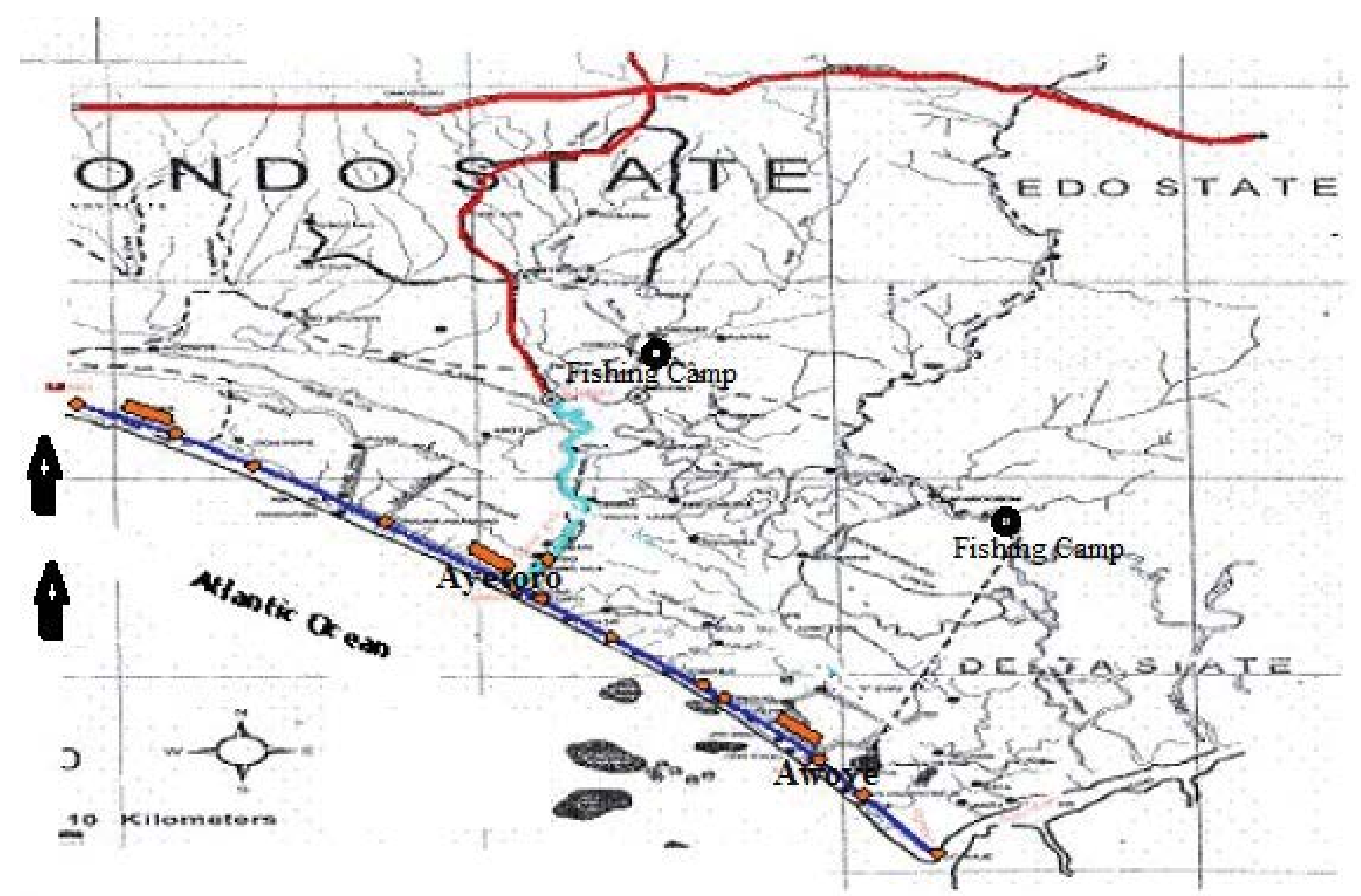

Figure 1: Map of Ondo state showing sampling locations in ILGA. 
Citation: Olusola JO, Festus AA (2015) Levels of Heavy Metal in Some Selected Fish Species Inhabiting Ondo State Coastal Waters, Nigeria. J Environ Anal Toxicol 5: 303. doi:10.4172/2161-0525.1000303

Page 3 of 8

of mangrove and fresh water swamps. The area is subject to tidal fluctuations with salt water incursion, two to ten months of the year. There are three subzones viz freshwater, brackish water and saltwater bordering the coastal communities. There are two hydrological cycles in the study area i.e. the wet and dry seasons. The wet season starts from May to October while the dry season spans November to April. There are over 80 fishing communities along the coastline and are the major fish producers in Ondo State [12]. Two of these communities (Ayetoro and Awoye) were purposely selected for this study based on extensive fishing activities in the towns, accessibility and their proximity to the Atlantic Ocean (Figures 1 and 2).

\section{Water sampling and analysis}

Sampling was conducted in January, 2014 representing the peak of dry season in Nigeria. Representative surface water samples were taken randomly below the surface film at a depth of $6-10 \mathrm{~cm}$ from three different sampling points along the coastline in each sampling locations into one liter acid leached polythene bottle. The water samples from the three different points were then mixed together to obtain a representative sample. The water sample were acidified to a $\mathrm{pH}$ of less than 2 by adding $2 \mathrm{ml}$ of analar grade conc. $\mathrm{HNO}_{3}$ and kept in the refrigerator prior to analysis. Heavy metal concentrations in water samples were determined having digested the samples in accordance with the standard procedure established by Parker. The water samples $(100 \mathrm{ml})$ were digested on a hot plate with the addition of $10 \mathrm{ml}$ concentrated nitric acid. The solution was heated to almost dryness and the residue dissolved with $10 \% \mathrm{HNO}_{3}$. The resulting solution was filtered through Whatman number 1 filter paper into $50 \mathrm{ml}$ standard flask and solution made to the mark. The concentrations of metals in each sample were determined against those of the blank and standard solutions using Buck scientific AAS, $200 \mathrm{~A}$.

\section{Fish sampling and analysis}

Three pieces each of individual fish species (Arius latisculatus, Cynoglossus browni, Caranx lugubris, Sardinella aurita, Caranx senegallus) were caught from the water bodies with the assistance of local fisher men. The samples were transported to the laboratory, where the scales were removed where applicable, rinsed with distilled water to remove any adhering substance and each fish separated into eye, head, gills, bones and muscles with dissecting knife. The different fish organs were then separately oven-dried at $105 \pm 2^{\circ} \mathrm{C}$ in a GallenKamp moisture extraction oven until constant weight was obtained and then ground into powder. Extraction of metals from the fish samples was by mixed acid digestion [13]. Samples of various organs ranging from $0.5 \mathrm{~g}$ to $1.09 \mathrm{~g}$ were accurately weighed and digested using $10 \mathrm{ml}$ of $65 \% \mathrm{HNO}_{3}$, $5 \mathrm{ml}$ of $37 \% \mathrm{HCl}$ and $2 \mathrm{ml}$ of $35 \% \mathrm{H}_{2} \mathrm{O}_{2}$ at $80 \pm 5^{\circ} \mathrm{C}$ in a fume chamber until colourless liquid was obtained. The solutions were allowed to cool at room temperature, filtered through Whatman number 1 filter paper into a $50 \mathrm{ml}$ standard flask. The filtrate obtained was made up to 50 $\mathrm{ml}$ mark with distilled water and used for heavy metals determination against those of the blank and calibration standards using atomic absorption spectrophotometer, Buck Scientific model, 200 A.

\section{Statistical analysis}

One way ANOVA and Duncan multiple range test were used to evaluate the significant difference in the concentration of different studied metals with respect to different fish organs. A probability at level of 0.05 was considered significant. Standard errors were also estimated.

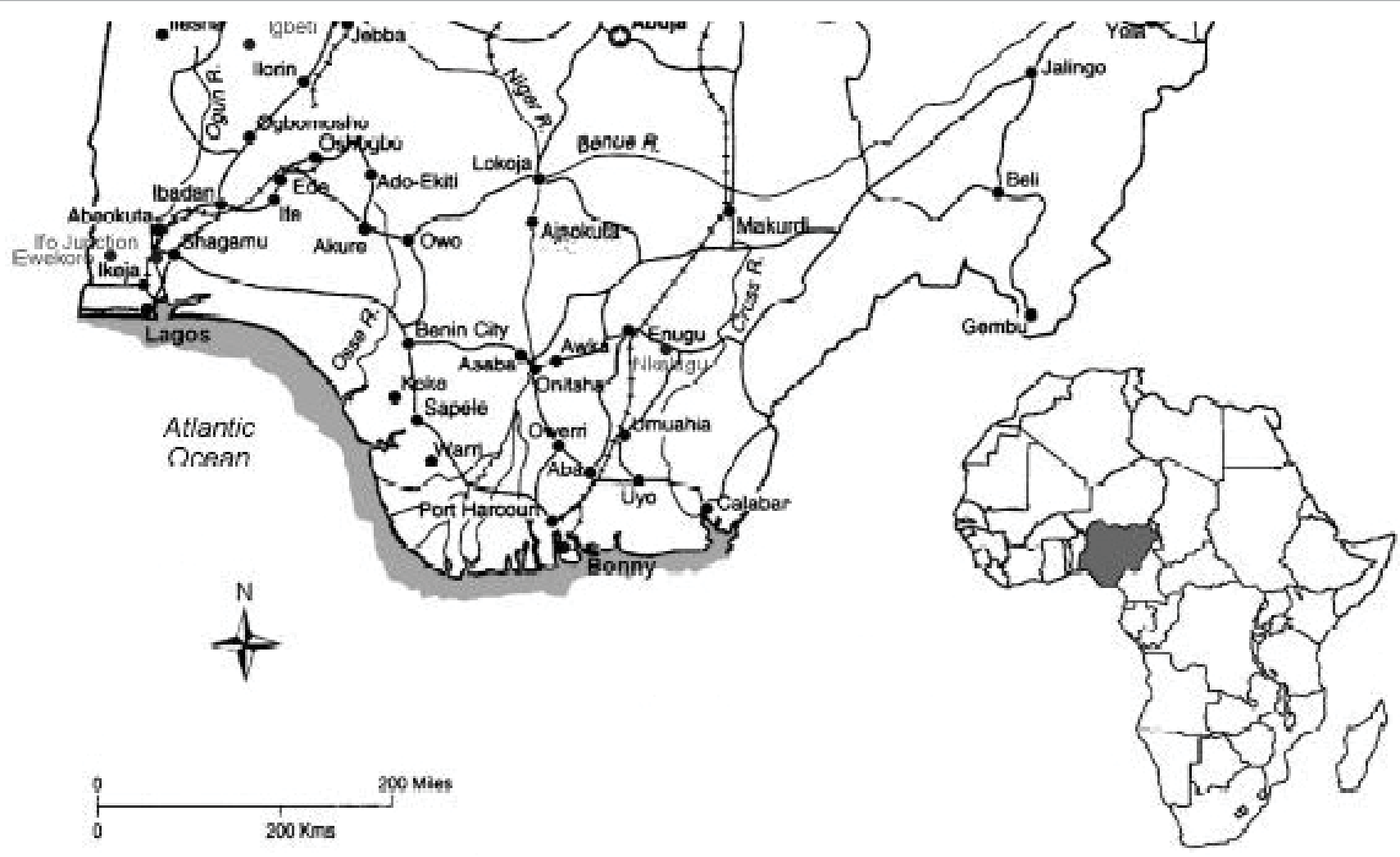

Figure 2: Map of Southern Nigeria showing major cities (Inserted is the area map of Africa). 
Citation: Olusola JO, Festus AA (2015) Levels of Heavy Metal in Some Selected Fish Species Inhabiting Ondo State Coastal Waters, Nigeria. J Environ Anal Toxicol 5: 303. doi:10.4172/2161-0525.1000303

Page 4 of 8

\section{Transfer factor (TF)}

The transfer factor in fish tissues with respect to the water where they were caught, was calculated according to Kalfakakour and AkridaDemertzi (2000) as follows $\mathrm{TF}=\mathrm{M}_{\text {tissue }} / \mathrm{M}_{\text {water }}$ where, $\mathrm{M}_{\text {tissue }}$ is the metal concentration in fish tissue and $\mathrm{M}_{\text {water }}$ metal concentration in water.

\section{Results and Discussion}

\section{Heavy metal levels in water}

Mean concentration and standard deviation of heavy metals level $(\mathrm{mg} / \mathrm{L})$ in the various water bodies are presented in Table 1a. The result were compare with water quality criteria for fresh water aquaculture (FWA) and World Health Organization standard for permissible limit of heavy metals in water (Tables $1 \mathrm{a}$ and $1 \mathrm{~b}$ ).

The differences in concentrations of some of the metals analysed in water samples from the three study locations were not signification $(p<0.05)$ (Table 1a). Metal concentration in water were found in the following order $\mathrm{Cr}>\mathrm{Pb}>\mathrm{Zn}>\mathrm{Cu}>\mathrm{Cd}>\mathrm{Ni}$ in Awoye community, whereas the order for Ayetoro was $\mathrm{Pb}>\mathrm{Cd}>\mathrm{Cu}>\mathrm{Cu}>\mathrm{Zn}>\mathrm{Cr}$ with nickel not detected in the water sample. In the Atlantic Ocean shoreline, the order was $\mathrm{Pb}>\mathrm{Cr}>\mathrm{Cu}>\mathrm{Zn}>\mathrm{Cd}>\mathrm{Ni}$. Comparison of mean concentrations of the metals in the coastal water with guideline values recommended by [14] (Table 1a). Showed compliance with $\mathrm{Cu}, \mathrm{Zn}$ and $\mathrm{Ni}$, while $\mathrm{Cr}$ (0.34-0.63) $\mathrm{Cd}(0.08-0.19)$ and $\mathrm{Pb}(0.34-0.79)$ were higher than the permissible recommended limits. This may be attributed to input from raw sewage, agricultural and industrial wastewater discharged into the water bodies or by surface runoffs laden with heavy metals from various towns/city bordering the coastal waters as earlier reported by Ololade $e t$ al. [15]. The high level of $\mathrm{Pb}$ in the coastal water could also be attributed to input from petrol used by fishing boats which are distributed all over the coastal water as means of transportation.

Comparing the heavy metals levels in Ondo State coastal water in this study with results from previous study within the area and the Niger Delta Mangrove Buguma Creek in River State (Table 1b), it is found that similar higher levels of $\mathrm{Cr}, \mathrm{Cd}$ and $\mathrm{Pb}$ (0.01-1.49, 0.01-0.11, $0.01-0.61 \mathrm{mg} / \mathrm{kg}$., respectively) were reported in the water sample and that of Buguma Creek in Delta State [16], but were higher compared to previous study on Ondo State Coastal Water (Table 1b) [17]. The difference in heavy metals concentrations may be associated with seasonal variation due to sampling periods. Seasonal variations could be associated with input of various substances into the water bodies through run-off in one-hand and dilution effect on the other hand during rainy season. The mean levels of $\mathrm{Cd}, \mathrm{Pb}, \mathrm{Cu}$ and $\mathrm{Zn}$ found in water of all the sampled locations exceeded the safe limits recommended to protect fish in freshwater aquaculture (Table 1a), which may pose a health risk for the fish populations in the coastal waters. This could indirectly threatens human health as a result of bioaccumulation of this metals by fish inhabiting the water [18]. Acconding to Heath [19], fish can regulate metal concentration to a certain limit after which bioaccumulation occurs. The concentration of metals in an organism's body vary from organ to organ and is a product of an equilibrium between the concentration of the metal in an organism's environment and its rate of ingestion and excretion [20].

\section{Heavy metal concentration in fish}

Mean concentrations of chromium, cadmium, lead, copper, zinc and nickel in muscle, head, gill, eye and bone of Arius latisculatus, Cynoglossus browni, Caranx lugubris, Sardinella aurita, Caranx senegallus from the coastal waters are shown in Tables $2 \mathrm{a}-2 \mathrm{e}$.

Fish are considered as biomonitors of aquatic ecosystems for estimating heavy metals pollution [4,21]. Different organs of fish are known to accumulate varied concentrations of heavy metals when they are exposed. In the present study, the concentration of heavy metals in the fish organs was in the following order gill $>$ eye $>$ bone $>$ muscle $>$ head. The criteria for choosing the various organs are based on the fact that, muscle, which is the edible part of the fish is considered a cheap source of protein and is widely consumed in the Southern part of Nigeria mostly among the middle and low income groups. Fish head (gills

\begin{tabular}{|c|c|c|c|c|}
\hline Metals & Awoye & Ayetoro & Ocean shore & FWA \\
\hline $\mathrm{Cr}$ & $0.63 \pm 0.001^{\mathrm{a}}$ & $0.04 \pm 0.014^{\mathrm{c}}$ & $0.34 \pm 0.001^{\mathrm{b}}$ & - \\
\hline $\mathrm{Cd}$ & $0.17 \pm 0.014^{\mathrm{a}}$ & $0.19 \pm 0.001^{\mathrm{a}}$ & $0.08 \pm 0.016^{\mathrm{b}}$ & $<0.0002-0.0018$ \\
\hline $\mathrm{Pb}$ & $0.52 \pm 0.141^{\mathrm{b}}$ & $0.34 \pm 0.014^{\mathrm{b}}$ & $0.79 \pm 0.001^{\mathrm{a}}$ & $0.001-0.007$ \\
\hline $\mathrm{Cu}$ & $0.26 \pm 0.001^{\mathrm{a}}$ & $0.18 \pm 0.001^{\mathrm{b}}$ & $0.27 \pm 0.018^{\mathrm{a}}$ & $<0.003$ \\
\hline $\mathrm{Zn}$ & $0.36 \pm 0.003^{\mathrm{a}}$ & $0.10 \pm 0.001^{\mathrm{c}}$ & $0.22 \pm 0.001^{\mathrm{b}}$ & 2.0 \\
\hline $\mathrm{Ni}$ & $0.01 \pm 0.001^{\mathrm{a}}$ & $\mathrm{BDL}$ & $0.01 \pm 0.001^{\mathrm{a}}$ & $<0.1$ \\
\hline
\end{tabular}

Data are mean of duplicate [2] determinations

BDL: Below instrument detection limit. Letters $a, b$ and $c$ show differences among the different locations. Data shown with different letters are statistically different at $P<0.05$ level.

Table 1a: Mean concentration of heavy metals in the various water bodies.

\begin{tabular}{|c|c|c|}
\hline Metals & Present study & Ondo coastal water \\
\hline $\mathrm{Cr}$ & $0.04-0.63$ & $0.10-27.10$ \\
\hline $\mathrm{Cd}$ & $0.08-0.19$ & $0.10-9.60$ \\
\hline $\mathrm{Pb}$ & $0.34-0.79$ & $0.20-9.60$ \\
\hline $\mathrm{Cu}$ & $0.18-0.27$ & $0.60-14.90$ \\
\hline $\mathrm{Zn}$ & $0.10-0.36$ & $0.60-17.60$ \\
\hline $\mathrm{Ni}$ & $\mathrm{BDL}-0.01$ & $2.0-36.00$ \\
\hline
\end{tabular}


Citation: Olusola JO, Festus AA (2015) Levels of Heavy Metal in Some Selected Fish Species Inhabiting Ondo State Coastal Waters, Nigeria. J Environ Anal Toxicol 5: 303. doi:10.4172/2161-0525.1000303

Page 5 of 8

\begin{tabular}{|c|c|c|c|c|c|c|}
\hline Metals & Muscle & Head & Eye & Gill & Bone & Overall mean \\
\hline $\mathrm{Cr}$ & $\mathrm{BDL}$ & $0.38^{\mathrm{b}}$ & $0.36^{\mathrm{b}}$ & $1.44^{\mathrm{a}}$ & $0.35^{\mathrm{b}}$ & 0.51 \\
\hline $\mathrm{Cd}$ & $0.32^{\mathrm{b}}$ & $0.33^{\mathrm{b}}$ & $0.32^{\mathrm{b}}$ & $0.65^{\mathrm{a}}$ & $0.32^{\mathrm{b}}$ & 0.32 \\
\hline $\mathrm{Pb}$ & $0.01^{\mathrm{b}}$ & $0.12^{\mathrm{a}}$ & $0.01^{\mathrm{b}}$ & $0.10^{\mathrm{a}}$ & $0.11^{\mathrm{a}}$ & 0.07 \\
\hline $\mathrm{Cu}$ & $\mathrm{BDL}$ & $0.55^{\mathrm{b}}$ & $\mathrm{BDL}$ & $1.51^{\mathrm{a}}$ & $0.57^{\mathrm{b}}$ & 0.53 \\
\hline $\mathrm{Zn}$ & $0.51^{\mathrm{b}}$ & $0.33^{\mathrm{c}}$ & $0.34^{\mathrm{c}}$ & $4.14^{\mathrm{a}}$ & $0.39^{\mathrm{c}}$ & 1.14 \\
\hline $\mathrm{Ni}$ & $\mathrm{BDL}$ & $0.05^{\mathrm{c}}$ & $0.03^{\mathrm{c}}$ & $0.06^{\mathrm{c}}$ & $0.01^{\mathrm{c}}$ & 0.03 \\
\hline
\end{tabular}

Data are mean of replicate [2] determinations.

BDL: Below instrument detection limit. Letters $a, b$ and $c$ show differences among the different tissues. Data shown with different letters are statistically different at $\mathrm{P}<0.05$ level.

Table 2a: Level of heavy metals in Arius latisculata organs $(\mathrm{mg} / \mathrm{kg})$

\begin{tabular}{|c|c|c|c|c|c|c|}
\hline Metals & Muscle & Head & Eye & Gill & Bone & Overall mean \\
\hline $\mathrm{Cr}$ & BDL & $\mathrm{BDL}$ & ----- & $0.63^{a}$ & $0.35^{\mathrm{b}}$ & 0.25 \\
\hline $\mathrm{Cd}$ & $0.31^{\mathrm{a}}$ & $0.33^{a}$ & ---- & $0.52^{\mathrm{a}}$ & $0.31^{a}$ & 0.37 \\
\hline $\mathrm{Pb}$ & $0.05^{c}$ & $\mathrm{BDL}$ & ----- & $0.08^{b}$ & $0.11^{\mathrm{a}}$ & 0.05 \\
\hline $\mathrm{Cu}$ & BDL & $\mathrm{BDL}$ & ---- & BDL & $0.57^{\mathrm{a}}$ & 0.14 \\
\hline $\mathrm{Zn}$ & $0.51^{a, b}$ & $0.36^{b}$ & ----- & $0.59^{a}$ & $0.39^{a, b}$ & 0.46 \\
\hline $\mathrm{Ni}$ & $0.01^{\mathrm{c}}$ & $0.03^{c}$ & ----- & $0.04^{c}$ & $\mathrm{BDL}$ & 0.02 \\
\hline
\end{tabular}

Data are mean of replicate [2] determinations.

BDL: Below instrument detection limit .Letters $a, b$ and $c$ show differences among the different tissues. Data shown with different letters are statistically different at $P<0.05$ level.

Table 2b: Level of heavy metal in Cynoglosus browni organs (mg/kg).

\begin{tabular}{|c|c|c|c|c|c|c|}
\hline Metals & Muscle & Head & Eye & Gill & Bone & Overall mean \\
\hline $\mathrm{Cr}$ & BDL & $0.31 b^{c}$ & $1.08^{b}$ & $2.92^{a}$ & $0.31^{\mathrm{bc}}$ & 0.93 \\
\hline $\mathrm{Cd}$ & $0.33^{b}$ & $0.33^{b}$ & $0.95^{b}$ & $2.57^{a}$ & $0.33^{b}$ & 0.90 \\
\hline $\mathrm{Pb}$ & $0.07^{b}$ & $0.01^{c}$ & $0.47^{a}$ & $0.92^{a}$ & $0.10^{b}$ & 0.31 \\
\hline $\mathrm{Cu}$ & $\mathrm{BDL}$ & BDL & BDL & $4.82^{\mathrm{a}}$ & $0.57^{b}$ & 1.08 \\
\hline $\mathrm{Zn}$ & $0.28^{c}$ & $0.37^{c}$ & $0.03^{b}$ & $2.27^{a}$ & $0.36^{c}$ & 0.86 \\
\hline $\mathrm{Ni}$ & $\mathrm{BDL}$ & BDL & $0.01^{b}$ & $0.01^{b}$ & $0.01^{b}$ & $<0.01$ \\
\hline
\end{tabular}

Data are mean of replicate [2] determinations.

BDL: Below instrument detection limit. Letters $a, b$, and $c$ show differences among the different tissues. Data shown with different letters are statistically different at $\mathrm{P}<0.05$ level.

Table 2c: Level of heavy metal in Caranx lugubris organs $(\mathrm{mg} / \mathrm{kg})$.

\begin{tabular}{|c|c|c|c|c|c|c|}
\hline Metal & Muscle & Head & Eye & Gill & Bone & Overall mean \\
\hline $\mathrm{Cr}$ & BDL & $0.40^{\mathrm{bc}}$ & $0.76^{b}$ & $3.41^{\mathrm{a}}$ & $0.36^{\mathrm{bc}}$ & 0.99 \\
\hline $\mathrm{Cd}$ & $0.34^{\mathrm{b}}$ & $0.19^{b}$ & $0.71^{b}$ & $3.18^{a}$ & $0.36^{b}$ & 0.96 \\
\hline $\mathrm{Pb}$ & $0.10^{d}$ & $0.27^{c}$ & $0.55^{\mathrm{b}}$ & $1.14^{a}$ & $0.09^{e}$ & 0.43 \\
\hline $\mathrm{Cu}$ & $\mathrm{BDL}$ & $\mathrm{BDL}$ & $\mathrm{BDL}$ & $5.72^{\mathrm{a}}$ & $0.67^{b}$ & 1.28 \\
\hline $\mathrm{Zn}$ & $0.31^{c}$ & $0.41^{c}$ & $0.78^{b}$ & $3.15^{a}$ & $0.44^{c}$ & 1.02 \\
\hline $\mathrm{Ni}$ & $\mathrm{BDL}$ & $0.02^{d}$ & $0.04^{d}$ & $0.07^{c}$ & $0.01^{d}$ & 0.03 \\
\hline
\end{tabular}

Data are mean of replicate [2] determinations.

BDL: Below instrument detection limit. Letters a, b, bc, c, d and e show differences among the different tissues. Data shown with different letters are statistically different at $\mathrm{P}<0.05$ level.

Table 2d: Level of heavy metal in Caranx senegallus organs $(\mathrm{mg} / \mathrm{kg})$.

\begin{tabular}{|c|c|c|c|c|c|c|}
\hline Metal & Muscle & Head & Eye & Gill & Bone & Overall mean \\
\hline $\mathrm{Cr}$ & BDL & $0.26^{c}$ & $0.81^{b}$ & $1.24^{a}$ & $0.32^{c}$ & 0.53 \\
\hline $\mathrm{Cd}$ & $0.31^{c}$ & $0.21^{d}$ & $0.71^{b}$ & $1.15^{\mathrm{a}}$ & $0.31^{c}$ & 0.54 \\
\hline $\mathrm{Pb}$ & $0.08^{b}$ & $0.07^{\mathrm{b}}$ & $0.32^{c}$ & $0.78^{a}$ & $0.12^{\mathrm{b}}$ & 0.27 \\
\hline $\mathrm{Cu}$ & $\mathrm{BDL}$ & $\mathrm{BDL}$ & BDL & $2.19^{a}$ & $0.59^{b}$ & 0.55 \\
\hline $\mathrm{Zn}$ & $0.32^{\mathrm{c}}$ & $0.38^{c}$ & $0.86^{b}$ & $1.27^{\mathrm{a}}$ & $0.39^{c}$ & 0.64 \\
\hline $\mathrm{Ni}$ & $0.02^{\mathrm{a}}$ & $\mathrm{BDL}$ & $0.04^{a}$ & $0.07^{a}$ & BDL & 0.03 \\
\hline
\end{tabular}

Data are mean of replicate [2] determinations.

BDL: Below instrument detection limit. Letters $a, b, c$, and d show differences among the different tissues. Data shown with different letters are statistically different at $\mathrm{P}<0.05$ level.

Table 2e: Level of heavy metal in Sardinella aurita organs $(\mathrm{mg} / \mathrm{kg})$.

inclusive) and born is used in the production of food additives for livestock, i.e. gelatin. Therefore, its health quality is also very important.

Metals concentration in gill could be due to the element complexing with the mucus, which is impossible to remove completely from between the lamellae before tissue is prepared for analysis. Corollary, high concentrations of metals in gill might be associated with the fact that during feeding and breathing processes, the water entering the 
fish mouth passes through the gills in the head, thus making the gills exposed to the metals [22]. Chromium concentration is significant $(\mathrm{p}<0.05)$ in almost all organs of fish species. The distribution pattern of chromium in the present study was in the deceasing order of gill $>$ eye $>$ head $>$ bone $>$ muscle in most fish species analysed. In other word, gill seemed to be the organ which accumulates the highest concentration of chromium. The highest value of $\mathrm{Cr}(3.41 \mathrm{mg} / \mathrm{kg})$ was observed in gill of Caranx senegallus (Table 2d). Chromium was not detected in muscle of all the species examined. Similar results were reported for a number of fish species, which show that muscle is not an active tissue in accumulation of metals $[23,24]$. The concentrations of chromium recorded in the present study were lower than the maximum allowable limit of $8 \mathrm{mg} / \mathrm{kg}$ in food [25].

Cadmium concentrations recorded in the fishes organs showed significant difference $(\mathrm{p}<0.05)$. The distribution pattern of cadmium was in the decreasing order gill $>$ eye $>$ muscle $>$ head $>$ bone. The highest $(3.18 \mathrm{mg} / \mathrm{kg})$ and lowest $(0.19 \mathrm{mg} / \mathrm{kg})$ level of Cd was found in gill and head of $C$. senegallus respectively. The concentration of cadmium in muscle recorded a comparable value in almost all the species of fish. Cadmium concentration in the muscle of the examined fish species followed a similar pattern ranging from $0.32 \mathrm{mg} / \mathrm{kg}$ Arius latisculata, $0.31 \mathrm{mg} / \mathrm{kg}$ Cynoglosus browni, $0.33 \mathrm{mg} / \mathrm{kg}$ Caranx lugubris, $0.34 \mathrm{mg} / \mathrm{kg}$ Caranx senegallus, $0.31 \mathrm{mg} / \mathrm{kg}$ Sardinella aurita, this may be due to long exposure period to $\mathrm{Cd}$ in the water where they dwell. Bone also shows a similar pattern of distribution among the examined species ranging from $0.31 \mathrm{mg} / \mathrm{kg}$ in Sardinella aurita $-0.36 \mathrm{mg} / \mathrm{kg}$ in Caranx senegallus. The concentration of $\mathrm{Cd}$ in bone and gill recorded comparable values in some of the examined species. The results indicate that the accumulation of Cd could occur in gill and other hard tissue such as bones. This is in agreement with the work of El-Nemr [26] who reported that Cd is stored in the body in various tissues including bone and exoskeleton. The acute toxicity of cadmium to aquatic organisms is variable, even between closely related species and is related to free ionic concentration of the metals. Cd interacts with the calcium metabolism in fish to cause abnormally low calcium levels (hypocalcaemia), probably by inhibiting calcium uptake from the water. However, high calcium concentration in water protects fish from cadmium uptake by competing at uptake site [2]. The maximum allowable level of $\mathrm{Cd}$ in fish for human consumption specified by the European Union is $0.05 \mathrm{mg} / \mathrm{kg}$. The observed mean concentration of cadmium $(0.27-0.96 \mathrm{mg} / \mathrm{kg})$ in this study is higher than the maximum allowable limits.

The present study shows that Copper recorded its highest concentration $(5.72 \mathrm{mg} / \mathrm{kg})$ in gill of Caranx senegallus (Table $2 \mathrm{~d}$ ). Concentrations of copper in the fish organs in general were in the order of gill $>$ bone $>$ head $>$ eye $>$ muscle. However, copper was not detected in the muscle of all the examined species. The low concentration of $\mathrm{Cu}$ observed in the fish species indicates that food is the primary pathway for uptake of copper in all examined species. Since these fish species are not fed it is expected that the level of copper will be low as observed in the research. Similar results reported by [27] shows lower concentration of $\mathrm{Cu}$ in muscle of uncultivated fish species. The mean concentration of $\mathrm{Cu}$ recorded in this study was much lower than maximum allowable limit $120 \mathrm{mg} / \mathrm{kg}$ in food [25].

Zinc is the only metal that is readily available in all the organs of all examined fish species. The abundance of zinc in all the fish part could be associated with the fact that these metals are naturally abundant in Nigerian soil and irrespective of the source; the final depositories are the aquatic systems. The highest concentration of zinc $(4.14 \mathrm{mg} / \mathrm{kg})$ was recorded in gill of $A$. latisculata (Table $2 \mathrm{a}$ ), The low concentration of zinc in the muscle of the examined fish species has been linked to lower level of binding proteins (metallothioneins) in the muscle. The mean concentration of $\mathrm{Zn}$ ranging from $0.64 \mathrm{mg} / \mathrm{kg}$ in $S$. aurita to $1.14 \mathrm{mg} /$ $\mathrm{kg}$ in A. latisculata in the examined fish species were lower compared to the maximum allowable limit of $50 \mathrm{mg} / \mathrm{kg}$ in food [25]. Chromium Copper and Zinc are essential elements and are carefully regulated by physiological mechanisms in most organisms. However, occurrence of excessive levels of them is regarded as potential hazards which can endanger both animal and human health [28-31].

The concentrations of nickel $(\mathrm{Ni})$ in fish organs were relatively low and of the order: gill $>$ eye $>$ head $>$ muscle $>$ bone. The highest concentration $(0.07 \mathrm{mg} / \mathrm{kg}$ ) was found in gill of C. senegallus (Table $2 \mathrm{~d})$, while the lowest $(0.001 \mathrm{mg} / \mathrm{kg})$ where detected was observed in bone tissue of $C$. lugubris [Table 2c]. The concentrations of nickel in the edible muscle of all examined species ranges from BDL - 0.02 $\mathrm{mg} / \mathrm{kg}$ in S. aurita. The result confirms that most fish species do not bioaccumulate the metal contrary to what was previously reported by Karadede et al. [29] and Mendil et al., [30]. The mean concentration of nickel in different fish species observed in this present study was below the permissible limit of $1.0 \mathrm{mg} / \mathrm{kg}$ prescribed by United State Environmental Protection Agency [25,32].

The distribution pattern of lead follows the decreasing order of gill $>$ head $>$ eye $>$ bone $>$ muscle. $\mathrm{Pb}$ recorded its highest concentration $(0.78 \mathrm{mg} / \mathrm{kg})$ in gill of $S$. aurita (Table 2e). The concentration of $\mathrm{Pb}$ in muscle ranged between $0.01 \mathrm{mg} / \mathrm{kg}$ to $0.10 \mathrm{mg} / \mathrm{kg}$. Bone showed a similar concentration range of between $0.10 \mathrm{mg} / \mathrm{kg}$ (Table 2c) to 0.12 $\mathrm{mg} / \mathrm{kg}$ (Table 2e). Lead is a neurotoxin that cause behavioral deficits in vertebrates and can cause decrease in survival, growth rate, learning and metabolisms [8]. Young stages of fish are more susceptible to lead than adults or eggs $[8,31]$. The mean concentration of $\mathrm{Pb}$ recorded in the fish species is higher than the permissible limit of $0.2 \mathrm{mg} / \mathrm{kg}$ in fish [25]. It should be noted that $\mathrm{Pb}$ and $\mathrm{Cd}$ accumulate in human tissues and hence are harmful to human health [18,33-35].

\section{Transfer factor}

The transfer factor (TF) in the examined fish species from water are presented in Tables $3 \mathrm{a}$ and $3 \mathrm{~b}$. Calculated transfer factors for water were generally greater than or equal to 1 except for $\mathrm{Pb}$ in some species [36]. Figure 1 shows the comparisons of the ratio of investigated heavy metals levels in fish/water. The concentration of metals in most of the fish species was higher than in the water where they are caught except for lead, thus suggesting bioaccumulation of these metals in the fish with respect to their concentrations in water as observed in Figure $1[37,38]$.

\begin{tabular}{|c|c|c|c|c|c|c|}
\hline & $\mathbf{C r}$ & $\mathbf{C d}$ & $\mathbf{P b}$ & $\mathbf{C u}$ & $\mathbf{Z n}$ & $\mathbf{N i}$ \\
\hline Arius latisculata & 1.51 & 4.15 & 0.09 & 2.00 & 5.11 & 27.00 \\
\hline Cynoglossus browni & 0.73 & 4.78 & 0.06 & 0.54 & 2.07 & 16.00 \\
\hline Caranx lugubris & 1.20 & 5.51 & 0.10 & 1.82 & 1.27 & 3.00 \\
\hline Sardinella aurita & 2.76 & 11.70 & 0.39 & 4.07 & 3.87 & 3.00 \\
\hline Caranx senegallus & 2.93 & 12.42 & 0.54 & 4.82 & 4.57 & 28.00 \\
\hline
\end{tabular}

Table 3a: Transfer factor from water to fish.

\begin{tabular}{|c|c|c|c|c|c|c|}
\hline & $\mathbf{C r}$ & $\mathbf{C d}$ & $\mathbf{P b}$ & $\mathbf{C u}$ & $\mathbf{Z n}$ & $\mathbf{N i}$ \\
\hline Arius latisculata & 1.50 & 4.00 & 0.09 & 1.96 & 5.18 & 3.00 \\
\hline Cynoglossus browni & 0.74 & 4.63 & 0.06 & 0.52 & 2.09 & 2.00 \\
\hline Caranx lugubris & 2.74 & 11.30 & 0.39 & 4.00 & 3.90 & 1.00 \\
\hline Sardinella aurita & 1.56 & 6.75 & 0.34 & 2.04 & 2.90 & 3.00 \\
\hline Caranx senegallus & 2.91 & 12.00 & 0.54 & 4.74 & 4.63 & 3.00 \\
\hline
\end{tabular}

Table 3b: Variability in species bioaccumulation of heavy metals. 
Citation: Olusola JO, Festus AA (2015) Levels of Heavy Metal in Some Selected Fish Species Inhabiting Ondo State Coastal Waters, Nigeria. J Environ Anal Toxicol 5: 303. doi:10.4172/2161-0525.1000303

Table $3 \mathrm{~b}$ shows variability in bioaccumulation of heavy metals by different species. This implies that inorganic contaminants such as heavy metals entering coastal waters may be concentrated by fishes to varying degree from waters, sediment or their food as observed in Figures 3 and 4 . This is in agreement with other works on pollutant transfer $[32,39,40]$

\section{Conclusion and Recommendations}

The obvious conclusion derivable from these results was that some heavy metals such as $\mathrm{Cd}$ and $\mathrm{Pd}$ found in fish muscle and water was higher than their allowable limits posing potential health risks on the surrounding communities that earn their livelihood from the water bodies considering the toxicity of the two metals and also on the fish population as a whole because, long term exposure of some heavy could lead to larval mortality and temporary reduction in growth of fish. Bioaccumulation potential of the studied heavy metals viz: $\mathrm{Cr}, \mathrm{Cd}$, $\mathrm{Pb}, \mathrm{Cu}, \mathrm{Zn}$ and $\mathrm{Ni}$ in muscle, head, gill, eye and bone of the five fish species from Ondo State coastal waters was organ specific. Generally, metal accumulation in organs of these species follows the decreasing order gill $>$ eye $>$ bone $>$ muscle $>$ head.

In view of the hazard associated with heavy metals consumptions, the following are recommended: Education and awareness campaign should be carried out by relevant agencies concerned with environmental sustainability to sensitize those living in coastal area on environmental impact of heavy metals. A proper monitoring

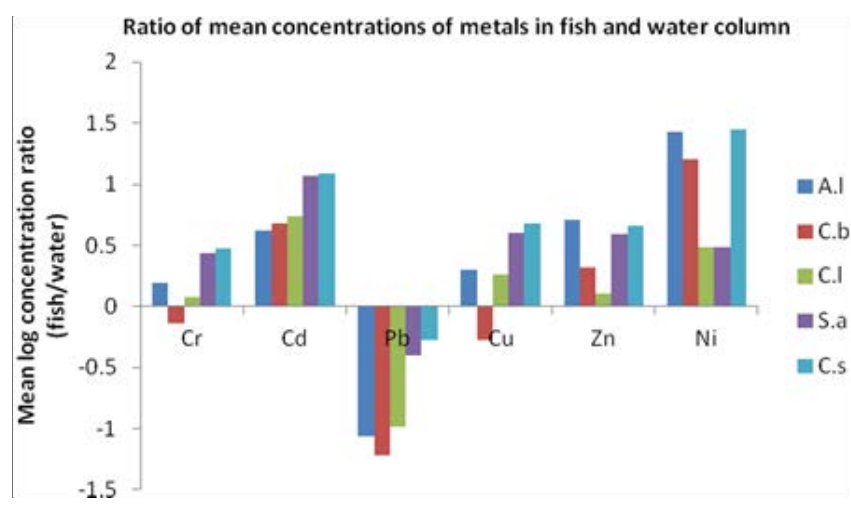

Figure 3: A plot of the ratio of mean concentrations of metals in fish and water column.

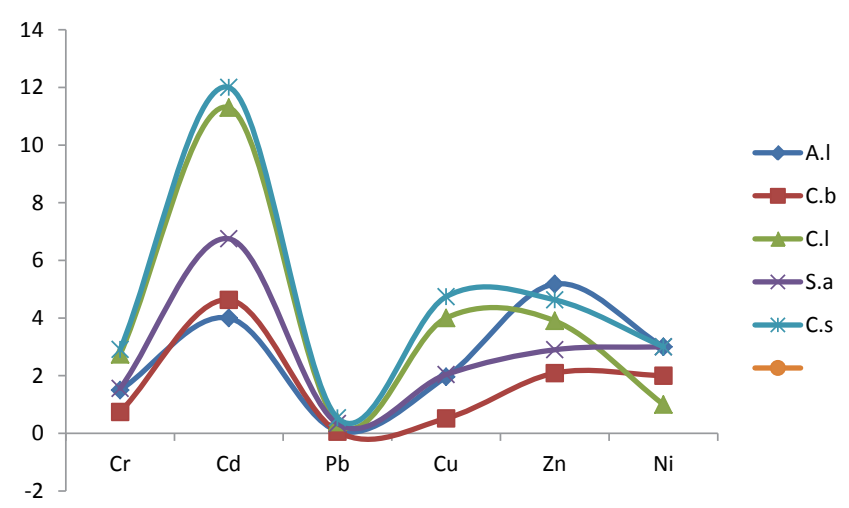

AL: Arius latisculatus, CB: Cynoglossus browni, CL: Caranx lugubris, SA Sardinella aurita, CS: Caranx senegallus

Figure 4: Shows variability in species bioaccumulation of heavy metals. programme for the water resources within the riverine area should be put in place and implemented by Government. There is need for continuous contaminants monitoring of the Ondo State coastal regions to ascertain the quality of habitats for resident and migratory fishes. The monitoring programs should not be limited to heavy metals only but also for hydrocarbons and PCBs and pesticides residues.

\section{References}

1. Abou-Arab AAK, Ayesh AM, Amra HA, Naguib K (1996) Characteristic levels of some pesticides and heavy metals in imported fish. Food Chem 57: 478-492.

2. Ita EO (1993) Inland Fishery Resources of Nigeria. CIFA Occasional paper 20: 94-100.

3. Ayoola SO, Kuton MP (2009) Seasonal variation in fish abundance and physico-chemical parameters of Lagos lagoon, Nigeria. AJEST 3: 149-158.

4. Blasco J, Arias AM, Saenz V (1999) Heavy metals in organisms of the River Guadalquivir estuary: possible incidence of the Aznalcóllar disaster. Sci Total Environ 242: 249-259.

5. Malik N, Biswas AK, Qureshi TA, Borana K, Virha R (2010) Bioaccumulation of heavy metals in fish tissues of a freshwater lake of Bhopal. Environ Monit Assess 160: 267-276.

6. Agah H, Leermakers M, Elskens M, Fatemi SM, Baeyens W (2009) Accumulation of trace metals in the muscle and liver tissues of five fish species from the Persian Gulf. Environ Monit Assess 157: 499-514.

7. Whitehead PJP (1985) FAO species catalogue. Clupeoid fishes of the world. An annotated and illustrated catalogue of the herrings, sardines, pilchards, sprats anchovies and wolfherrings. Chirocentridae, Clupeidae and Pristigasteridae 7 : 90-114.

8. Martinez CB, Nagae MY, Zaia CT, Zaia DA (2004) Acute morphological and physiological effects of lead in the neotropical fish Prochilodus lineatus. Braz J Biol 64: 797-807.

9. Ali MHH, Fishar MRA (2005) Accumulation of trace metals in some benthic invertebrate and fish species relevant to their concentration in water and sediment of lake Qarun, Egypt. Egyptian Journal of Aquatic Resources 31: 289-301.

10. Solarin BB, Williams AB, Hamzat MB, Rabiu A, Oguntade OR, et al. (2010) Report on survey of fish and other living resources of the Nigerian coastal waters conducted between 14th April and 6th June 2009. NIOMR, Lagos, 57

11. Adeparusi EO, Ajibefun Al, Akeremale EO (2003) Smoke Curing of Fish by Artisanal Fisher Folks in llaje, Ondo State, Nigeria. ASSET Series A 3: 101-109.

12. Akegbejo-Samson Y (1995) Ecology of the Fisheries Resources of Coastal Wetlands of Ondo State and Its Management Implications. Ph.D. Thesis, Federal University of Technology, Akure, 297.

13. Khansari FE, Khansari MG, Abdollahi M (2005) Heavy metals content of canned tuna fish. Food Chemistry 93: 293-296.

14. WHO-IPCS-Environmental Health Criteria Report, with ILO and UNEP (1987) International Program on Chemical Safety. Geneva, Switzerland.

15. Ololade IA, Lajide (2010) Post-impact assessment of oil spillage on wate characterization. Applied Ecology and Environmental Research 8: 191-205.

16. Oribhabor BJ, Ogbeibu AE (2009) Concentration of heavy metal in Niger Delta mangrove creek, Nigeria. Global Journal of Environmental science 8: 1-10.

17. Asaolu SS, Ipinmoroti KO, Adeeyinwo CE, Olaofe O (1997) Interrelationship of heavy metal contamination in water, sediment and fish of Ondo State coastal waters. African Journal of Science 1: 55-60.

18. Senarathne $P$, Pathiratne KSA (2007) Accumulation of heavy metal in food fish Mystus gulio inhabiting Bolgoda lake, Sri lanka. J Aquat Sci 12: 61-75.

19. Heath AG (1991) Water pollution and fish physiology. Lewis publisher, Boca Raton, Florida, USA, pp. 359

20. Mohammed A, Al-kahtani (2009) Accumulation of heavy metals in Tilapia fish Oreochromis niloticus from Al-khadoud spring, Al-hassan, Saudi Arabia. Am J Appl Sci 6: 2024-2029

21. Peakall D, Burger J (2003) Methodologies for assessing exposure to metals: speciation, bioavailability of metals, and ecological host factors. Ecotoxicol Environ Saf 56: 110-121. 
Citation: Olusola JO, Festus AA (2015) Levels of Heavy Metal in Some Selected Fish Species Inhabiting Ondo State Coastal Waters, Nigeria. J Environ Anal Toxicol 5: 303. doi:10.4172/2161-0525.1000303

Page 8 of 8

22. Sadiq M, Zaidi TH, Amir-ul-Hoda, Mian AA (1982) Heavy metal concentrations in shrimp, crab, and sediment obtained from AD-Dammam sewage outfall area. Bull Environ Contam Toxicol 29: 313-319.

23. Carpene E, Vasak M (1989) Hepatic Metallothionein from goldfish (Carassius auratus). Comp Biochem Physiol 92B: 463-468.

24. Adefemi OS, Olaofe O, Asaolu SS (2004) Concentration of Heavy metals in water sediment and fish parts (Illisha africana) from Ureje dam, Ado-Ekiti, Ekiti State. Nigerian Journal of Biology and Physical Sciences 3: 111-114.

25. http://www.extremehealth.com

26. El-Nemr A (2003) Concentrations of certain heavy metals in imported frozen fish in Egypt. Egypt J Aquat Biol \& Fish 7: 139-154.

27. Dallinger R, Kautzky H (1985) The importance of contaminated food for the uptake of heavy metals by rainbow trout (Salmo gairdneri): a field study. Oecologia (Berlin) 67: 82-89.

28. Wright DA, Welbourn $P$ (2002) Environmental Toxicology. Cambridge press, Cambridge, UK.

29. Karadede $H$, Unlü $E$ (2000) Concentrations of some heavy metals in water sediment and fish species from the Atatürk Dam Lake (Euphrates), Turkey. Chemosphere 41: 1371-1376.

30. Mendil D, Demirci Z, Tuzen M, Soylak M (2010) Seasonal investigation of trace element contents in commercially valuable fish species from the Black sea, Turkey. Food Chem Toxicol 48: 865-870.

31. Shah SL (2006) Hematological parameters in tench Tinca tinca after short term exposure to lead. J Appl Toxicol 26: 223-228.
32. Fowler SW (1982) Biological transfer and transport processes. Pollutant Transfer and Transport in the Sea Kullenberg G (Editor) CRC press Inc. Boca Raton, USA, pp: 1-65.

33. Amadi AA (1990) A comparative ecology of estuaries in Nigeria. Hydrobiologia 208: 27-28.

34. ANZECC (2000) Australian and New Zealand Water Quality Guidelines Australia and New Zealand Environment and Conservation Council and Agriculture and Resource Management Council of Australia and New Zealand, Canberra

35. Buttner JK, Soderberg RW, Terlizzi DE (1993) An Introduction to Water Chemistry in Freshwater Aquaculture. Northeastern Regional Aquaculture Center, University of Massachusetts, Dartmouth, North Dartmouth, Massachusetts, USA, pp 4.

36. Department of Water Affairs and Forestry (1996) South African Water Quality Guidelines (2ndedn). Agricultural Water Use: aquaculture 6: 185.

37. Froese R, Pauly D (2009) "Caranx senegallus" in Fish Base.

38. Kalfakakou V, Akrida-Demertzi K (2000) Transfer factors of heavy metals in aquatic organisms of different trophic levels. Conference: Biopolitics and International cooperation-The bio-environment 1: 768-786.

39. Lawson TB (1995) Fundamentals of Aquacultural Engineering. Chapman and Hall Publishers, New York, USA.

40. Adeyeye El (1994) Determination of trace heavy metals in Illisha Africana fish and in associated water and sediment from some fish ponds. Int J Environ Stud 45: 231-238. 